\title{
COURT AND STATE IN THE ROMAN EMPIRE- DOMESTICATION AND TRADITION IN COMPARATIVE PERSPECTIVE
}

\author{
Peter Fibiger Bang
}

\begin{abstract}
Such a degree of obedience is also shewn by servants to their masters, and looked upon by them as a source of blessings. Hence for the disciples of His Majesty [the Emperor], it was necessary to add something, the prostration of the sijdah; and they look upon a prostration before His Majesty as a prostration performed before God; for royalty is an emblem of the power of God, and a light-shedding ray from this Sun of the Absolute. Viewed in this light, the prostration has become acceptable to many, and proved to them a source of blessings upon blessings. But as some perverse and dark-minded men look upon prostration as blasphemous man-worship, His Majesty, from his practical wisdom, has ordered it to be discontinued by the ignorant, and remitted it to all ranks, forbidding even his private attendants from using it in the Darbár $i^{\prime} A^{\prime} m$ (general court days). ${ }^{1}$
\end{abstract}

This discussion of prostration as a ritual of greeting used by a select and specially favoured group of courtiers to pay obeisance to Akbar, the Mughal emperor (1556-1605) appears in the copious manual of his realm written by the nobleman and ideologue Abul Fazl. The Mughals self-consciously presented themselves as rulers in the grand traditions of central Asia and of Persia. They boasted descent from Timur, the Turko-Mongol conqueror formerly known as Tamerlane, and championed a Persianate style of culture. Persian was the preferred or privileged language at court. Shahjahan, the grandson of Akbar, even had his audience halls designed metaphorically to emulate Persepolis. ${ }^{2}$ This was the fabled palace of the Achaemenids which the victorious Macedonian king Alexander had later senselessly burned down at the end of

1 Abul Fazl, Ain-i-Akbari I, 74 [H. Blochman, trans. (Calcutta 1927-1949) vol. 1, pp. 158-19]. Apart from the sijdah, the more regular forms of greeting were called the kornish (right hand on forehead which is then bent down) and the tasli'm (back of right hand placed on ground, raised up gently and when standing erect palm of hand on crown of head). John F. Richards, The Mughal Empire. The New Cambridge History of India, vol. 1.5 (Cambridge 1993) pp. 47-49 for a brief discussion.

${ }^{2}$ See the contribution of Ebba Koch in this volume; eadem, 'Diwan-i 'Amm and Chihil Sutun: The Audience Halls of Shah Jahan', Muqarnas 11 (1994) pp. 143-165. 
a drunken party. Rightly or wrongly, the act of prostration, whatever its varying historical forms, holds a prominent place in the Western historiographical conception of Persian imperial lordship. The ancient Greeks and Romans frowned on the performance of the ritual they described with the term proskunésis. Prostration in front of the ruler was reproached as a humiliating act of submission not becoming of free men; it was a degrading act of slavery.

One of the main charges brought against Alexander by posterity was that he had allowed himself to be lured by the splendour and rituals of the Persian court and had forgotten about his Greek and Macedonian roots. Later historians celebrated in their works an episode where the nobleman Callisthenes had spoken out against the plans of Alexander, prompted by the advice of a certain Anaxarchos, to demand prostration of his nobles now that he had won the Achaemenid throne:

It was improper of you to take the lead in this topic; you should rather have remembered that you are not attending, nor advising a Cambyses or Xerxes, but a son of Philip, a descendant of Heracles and of Aecus, whose forefathers came from Argos to Macedonia, and have continued to rule the Macedonians, not by force, but in accordance with custom and law. ${ }^{3}$

In Graeco-Roman political discourse, prostration/proskunesis was identified with tyranny and despotism, violent oppression rather than the rule of law. Roman emperors were repeatedly reminded not to demand such excessive demonstrations of loyalty from their nobility. Tiberius, emperor CE 14-37, is even reported once to have tripped in his attempt to avoid a senator who threw himself at his feet. ${ }^{4}$ Emperors who less carefully upheld the etiquette of modesty regulating the interaction of ruler and aristocracy were frequently subjected to hostile criticism. The reputations of emperors such as Caligula, Domitian and later Galerius and Diocletian have all been blackened by accusations of megalomania and tyranny. By accepting or demanding the so-called proskunesis, it was alleged, they allowed barbarian and Persian ways to debase the proud traditions of Roman liberty. ${ }^{5}$ This kind of critique, however, should not be mistaken, as it often is, for evidence of direct

\footnotetext{
${ }^{3}$ Arrian Anabasis IV, 11, 6 (oude biai, alla nomoi). Cf. Diana Spencer, The Roman Alexander (Exeter 2002).

${ }^{4}$ Suet. Tiberius 27.

${ }^{5}$ E.g. Philo Leg. ad Gaium 116 (Caligula); Ammianus Marcellinus 15, 5, 18 (Diocletian); Lactantius de mort. persc. 21, 2 (Galerius).
} 
emulation or introduction of Persian court ceremonial by Roman emperors. ${ }^{6}$ The idea of Persian imperial tyranny was a Graeco-Roman, and later Western, caricature, a cultural construct-monarchs in the Persian tradition were as we have just seen equally subject to critique and constraints. The bugbear notion of the Persian Great King served as a cultural stereotype which gave expression to a basic conflict within Graeco-Roman culture: ${ }^{7}$ city-state and imperial majesty co-existed uneasily. This paper will examine that tension through the prism of the sociology of Norbert Elias and portray it as a specific expression of a conflict and social dialogue characteristic not of the Roman court in particular, but of monarchical societies in general.

\section{A Roman Court or the Aristocratic Republic Domesticated?}

It has been one of the major concerns of modern Roman historiography to explain the nature of the relationship between the personal rule of the emperor and the old, legal institutions of the Roman republic which continued after the institution of monarchy under Augustus (31 BCE-CE 14). As the centre of government moved from the senate to the corridors of the imperial household, the state changed character.

${ }^{6}$ Pace Rowland Smith, 'The imperial court of the late Roman empire, c. AD 300c. AD 450', in: The Court and Court Society in Ancient Monarchies, Anthony S. Spawforth, ed. (Cambridge 2007) pp. 157-232 [partly following Aloys Winterling, ed., Zwishen "Haus" und "Staat": Antike Höfe im Vergleich (Munich 1997) p. 161n29]. The point was established by András Alföldy, Die monarchische Repräsentation im römischen Kaiserreiche (Darmstadt 1970) pp. 6-25. H. Stern's discussion ['Remarks on the 'Adoratio' under Diocletian', Journal of the Warburg and Courtauld Institutes 17 (1954) pp. 184-89] of late antique ceremonial changes to the imperial audience does not show any direct Persian influence behind these developments. The key point of Alföldy was not to deny the more rigidly hierarchical image projected by late antique imperial ceremony, but to make less of the contrast with the preceding period than previous scholars had done; the Princeps was already an august, quasi-divine lord. Similarly, as Sabine G. MacCormack showed in her study of late antique monarchical symbolism [Art and Ceremony in Late Antiquity (Berkeley; Los Angeles 1981)], not all aspects of the earlier ideal of a civic, accessible ruler disappeared.

7 The claim, e.g. of Mario Pani [La Corte dei Cesari (Rome; Bari 2003) pp. 73-104] that the Roman monarchy was torn between an Eastern and a Western model, therefore, seems of doubtful value. A clear distinction between two such models would in any case be difficult to identify by the time of the Roman monarchy. Cultural exchange, back and forth, had been much too intense and had a thousand-year-old record in the Mediterranean. Alexander might, for instance, have been accused of adopting Eastern ways, but following in his footsteps, Greek was elevated to a position of prominence in the Levant and the Middle East. 
Historians, equipped with the instruments of constitutional and administrative study, however, have found it difficult to account for this change. They have addressed the problem primarily as a question of the growth of formal bureaucracies and debated arcane details of public law to determine whether the imperial household was a public or a private institution. ${ }^{8}$ Others, more interested in the naked realities of power have preferred to follow in the footsteps of the senator Tacitus. A historian with a more than sentimental attachment to the Republican constitution, he famously dismissed what survived of it under the rule of the emperors as an empty shell. The Principate, the label which is normally tagged to the monarchy between $31 \mathrm{BCE}$ and CE 235 to emphasise the idea that the emperor was merely the leading citizen, the first among equals, was from a Tacitean perspective a sham devoid of political content. ${ }^{9}$ But whether one focuses on private intrigue and patrimonial rule or the public realm of law, formal bureaucracy and politics, the surviving institutions of the republic and the imperial monarchy continue to seem fundamentally foreign to each other.

Court history would seem to offer an avenue to cut across these divisions, as pointed out in recent years. ${ }^{10}$ In the work of Norbert Elias, the court is theorised, not merely as a private patrimonial establishment,

8 Theodor Mommsen, Römisches Staatsrecht, bd. 2, 2 (Leipzig 1887); Heinrich Otto Hirschfeld, Die kaiserlichen Verwaltungsbeamten bis auf Diocletian (Berlin 1905); Fergus Millar, The Emperor in the Roman World (London 1977) pp. 175-202; Elio Lo Cascio, Il Princeps e il suo impero. Studi di storia amministrativa e finanziaria romana (Bari 2000) pp. 97-150, 163-176.

9 The most famous modern Tacitean analysis of the Augustan monarchy is Ronald Syme's classic, but still fresh The Roman Revolution (Oxford 1939).

${ }_{10}$ Andrew Wallace-Hadrill, 'The Imperial Court', in: The Cambridge Ancient History, A.K. Bowman et al., eds., 2nd Ed., vol. X (1996) pp. 283-308; Aloys Winterling, ed., Zwishen "Haus" und "Staat". Antike Höfe im Vergleich (Munich 1997); idem, Aula Caesaris. Studien zur Institutionalisierung des römischen Kaiserhofes in der Zeit von Augustus bis Commodus (31. v. Chr.-192 n. Chr.) (Munich 1999); Pani, La Corte dei Cesari; Jeremy Paterson, 'Friends in high places: the creation of the court of the Roman emperor', in: The Court and Court Society in Ancient Monarchies, Anthony J.S. Spawforth, ed. (Cambridge 2007) pp. 121-56, and Smith, 'The imperial court of the late Roman empire'. Much of the textual evidence was assembled in Ludwig Friedländer's, mostly antiquarian, portrait of the Roman court [Darstellungen aus der Sittengeschichte Roms, 10. Aufl., Bd. 1 (Leipzig 1922) vol. 1, pp. 33-103]. The attempt of Alexander Demandt, Das Privatleben der römischen Kaiser (Munich 1997) to draw attention to the "private lives" of Roman emperors has some merit, but remains analytically a dead end because it insists on the category "private life" when it is clear that, in a court, this area of activity was inseparable from high politics. 
but as a public theatre of government and politics characterised by its own particular way of functioning; it provided an interface between monarch and political elite, the aristocracy. By transforming his household into a court the emperor could hope to attract and integrate the nobility into the government of his extensive realm. High offices and rewards distributed through the court, were supposed to make life in the service of the monarch more attractive to the landed aristocracy than retention of its old political independence. ${ }^{11}$ The rise of an imperial court entailed, in Elias' terms, a domestication and disciplining of the old senatorial, republican élite. The concepts of domestication and disciplining, however, must be used cautiously. Even more than a sociologist of court societies, Elias was a theorist of modernity. His model was based on the late seventeenth- and eighteenth-century absolutist French court to which he ascribed a pivotal position in the development of modern statehood and pacified civil societies. Government in the Roman Empire evolved under very different conditions. The style of rule and administration was much less intense than the forms of social control which gradually developed between the 17th and 19th centuries in European states. Elias may also in general have inflated the capacity of monarchs to control their courts. Yet, history abounds with examples of weak rulers. Rome is no exception. Nevertheless, with these caveats in mind, domestication and disciplining do seem apposite in the Roman case. ${ }^{12}$ The imperial monarchy was erected on

${ }^{11}$ Elias' ideal-type of the court was developed first in his study of Versailles. Here the emphasis was more narrowly placed on the mechanics of court society and the ability of the monarch to control and manipulate the nobility. In the later Über den Process der Zivilisation (1939/1997), particularly Bd. 2: 132-465 ('Zur Soziogenese des Staates' and 'Zusammenfassung'), the scope of the analysis was broadened to embed the model of the court more firmly within wider social developments and processes of state formation. For a general critique, see Jeroen Duindam, Myths of Power: Norbert Elias and the Early Modern European Court (Amsterdam 1995).

${ }^{12}$ Jeroen Duindam, Vienna and Versailles. The Courts of Europe's Dynastic Rivals, 1550-1780 (Cambridge 2003) emphasises the frequently weak position of the early modern French and Austrian Habsburg monarchies; collaboration more than domestication was the key component of court politics. See Sebastian Olden-Jørgensen, 'At vi maa frycte dig af idel kjærlighed-magtudøvelse og magtiscenesættelse under den ældre danske enevælde', Fortid og Nutid (1997) pp. 239-253, and his 'Hofkultur, ritual og politik i Danmark 1536-1746', in: Ritualernes Magt. Ritualer i europoisk historie 500-2000, Ulrik Langen, ed. (Roskilde 2002) both studies describing the domesticating capacity of the early-modern absolutist Danish court. At any rate, domestication, used flexibly and not as the only important aspect of court politics, does hold some analytical advantages for the Roman historian: it situates the process of the subjection 
the ruin of many aristocratic houses whose members and properties fell victim to the struggle for sole power among the leading magnates and generals. It was a weary senatorial élite, exhausted and depleted by several rounds of vicious civil wars, which eventually resigned itself to the metamorphosis of Octavian, the adopted heir of Julius Caesar, into the solemn world ruler Augustus. Over the following century, occasional spurts of proscriptions and summary executions reminded the senate of the price of disloyalty to the monarch.

Conflict, however, may also be a sign of relative failure. The continued need to pay heed to the old established republican governmental machinery, it has recently been suggested by Aloys Winterling in a thought-provoking study, is a sign of the lack of integration between court and society. The Roman world had been shaped decisively by the city-state and remained impermeable during the first centuries of monarchy to the attempts by the emperors to transform it. The Caesars, for instance, had not been able to supplant the old republican system of offices and orders with a hierarchy of rank of their own design. The imperial household remained the centre of a Hof ohne 'Staat'. ${ }^{13}$ This is an elegant hypothesis; it also fits well with professional prejudice among us historians always displaying a preference for the individual and specific characteristics of a culture. The notion of Hof ohne 'Staat' accords that crowning achievement of Graeco-Roman civilisation, the city-state, a primary role in the evolution of a wholly distinct Roman form of imperial court. Admittedly, any satisfactory explanation of the Roman court will have to take its republican heritage into account. Republican notions undoubtedly represent a significant aspect of what gives the study of the Roman court its particular flavour. The vestiges of republican political culture offer an important part of the explanation for the relatively frequent turn-over of monarchs and dynasties, which Scheidel has shown seems to be a distinct feature of Roman imperial history, particularly compared to the monarchies of earlymodern Europe. The emperor-to use the key insight of Egon Flaig's admirable study - was challengeable; his person and family could be

of the Roman republican aristocracy to the rule of one man firmly within the context of a court society rather than drawing on a-historical analogies to modern dictatorships and totalitarian states, as is done e.g. by Vasily Rudich, Dissidence and Literature under Nero: the Price of Rhetoricization (London 1997), and Maria H. Dettenhofer, Herrschaft und Widerstand im augusteischen Principat. Die Konkurrenz zwischen res publica und domus Augusta (Stuttgart 2000).

${ }_{13}$ Winterling, Zwishen "Haus" und "Staat". 
substituted. ${ }^{14}$ But the idea of a 'court without state' is too general and misleading; it exaggerates the specificity of the Roman court and in so doing seems to me to misrepresent the role of republican political culture and institutions within the monarchical system. Emperors and dynasties may have been more easily changed than in some other cultures. But the monarchy as such was solid and stable; the remaining republican institutions were, as Winterling openly admits, not the seat of the state. They did not represent an alternative to monarchy; they were unable to take over the functions of government on their own.

The basic premise of Winterling's thesis that the resilience of republican political titles, offices and institutions is a sign of the very limited domestication of the imperial aristocracy achieved by the court, is highly questionable. Before anything else, as Elias pointed out, the monarch is the leader of aristocratic society to which he himself belongs. ${ }^{15}$ The king had to appeal to and reflect the culture and sentiments of the aristocracy. Few courts have articulated this issue more acutely than the monarchy created under Augustus. ${ }^{16}$ In Rome the elite was defined by a centuries-old tradition of service to the state and a firmly entrenched ideology celebrating the freedom, libertas, procured for the Roman people by the legendary founder of the Republic, the elder Brutus. According to tradition he had ousted the last of the kings, Tarquinius, who just to avoid any trace of ambiguity had been stigmatised with the epithet 'Superbus', the 'haughty'. The title of rex, king, was anathema in Roman political discourse and had become synonymous with illegitimate tyranny. Octavian's own entry onto the stage of high politics only followed in the chaotic aftermath of the successful attempt of the younger Brutus and Cassius to mobilise these sentiments to form the conspiracy which ended with the murder of the dictator Caesar, on the Ides of March 44 BCE, for fear

${ }^{14}$ As pointed out by Egon Flaig, Den Kaiser herausfordern: Die Usurpation im Römischen Reich (Frankfurt 1992). Cf. W. Scheidel, 'Towards a comparative study of monarchical succession and dynastic continuity', forthcoming.

${ }^{15}$ Norbert Elias, Die höfische Gesellschaft. Untersuchungen zur Soziologie des Königtums und der höfischen Aristokratie mit einer Einleitung: Soziologie und Geschichtswissenschaft (Berlin 1969) p. 278.

${ }^{16}$ The classic, and in many ways unsurpassed, study of the transition to monarchy remains Ronald Syme, The Roman Revolution (Oxford 1939). Josiah Osgood, Caesar's Legacy. Civil War and the Emergence of the Roman Empire (Cambridge 2006) brings the tradition up to date. Kurt Raaflaub and Mark Toher, eds., Between Republic and Empire. Interpretations of Augustus and His Principate (Oxford 1990) is a strong collection of articles. 
he was transforming himself into a king. Octavian was quick to learn. In the final struggle for supremacy, the heir of Caesar deftly exploited Roman republican traditions of liberty. Antony, his rival, was vilified as harbouring dreams of an Oriental despotism and accused of plotting together with his mistress, the queen of Egypt Cleopatra, to move the capital of the empire to Alexandria. ${ }^{17}$ When victory was secure and sole rule his, Octavian went out of his way to avoid following in the ill-fated footsteps of Caesar. The time-honoured republican constitution was ostensibly re-instated, or as the emperor liked to phrase it, 'transferred' as a gift from him to the senate and people. ${ }^{18}$ Studiously avoiding the title of king, Octavian would henceforth reign as Augustus, the solemn one; the revolutionary leader had reinvented himself as patron of the state and guardian of the republic-the first citizen among his senatorial peers.

But cultural and symbolic continuity masked a process of profound change. The old republican institutions were not simply left intact; they were mobilised and refashioned to suit the demands of the new absolutism. Not for the last time in history, renovation turned out to be ostensibly more traditional in its outlook than the tradition it was meant to revive. Claudius, the emperor of the Julio-Claudian dynasty known for his stammer and with an eccentric delight in antiquarian study, only had the accent wrong, not the spirit, as he professed his official commitment to the preservation of 'the good old' ways by reintroducing all sorts of quaint and obscure customs and practices against the backdrop of a bemused Roman public. ${ }^{19}$ The Augustan monarchical settlement involved a thorough reorganisation and reorientation of the old republican political order..$^{20}$ The army was now controlled by the emperor; he was commander-in-chief and the title of Impera-

${ }^{17}$ Cf. Richard Beacham, 'The Emperor as Impressario: Producing the Pageantry of Power', in: The Cambridge Companion to the Age of Augustus, Karl Galinsky, ed. (New York 2005) pp. 152-59, though too "loyal" to the Augustan version. For a wider study of the image of Cleopatra in Roman culture, see Diana Kleiner, Cleopatra and Rome (Cambridge, Mass. 2005).

${ }_{18}$ Augustus, Res Gestae, chap. 34: rem publicam ex mea potestate in senat[us populique Rom]ani [a]rbitrium transtuli. Quo pro merito meo senatu[s consulto Au]gust[us appe]llatus sum.

${ }_{19}$ Suet. Claudius 16 (censorship imbued with a spirit of archaic eccentricity); 21, 2; 22 (reviving obsolete rituals, as well as introduction of novelties); 41-42 (antiquarian study).

20 The discussion of Mommsen, Römisches Staatsrecht, remains valuable on many points. 
tor became a preserve of the imperial majesty. Celebration of military triumphs through the streets of Rome-the crowning achievement of a noble career during the time of republican politics and a prize coveted by all the old aristocratic families-was quickly reserved for the reigning monarch and his family. Behind the proud claim 'Res Publica Restituta' a new, if not exactly invented, then certainly reinvented order was being harnessed to serve the needs of imperial monarchy. ${ }^{21}$ This meant reinforcing the dignity of hierarchy and the preservation of privilege. ${ }^{22}$ The two highest aristocratic orders of Roman society, the senatorial and the equestrian, received more strict regulation and greater formal demarcation than before. The property qualification of senators was significantly raised; 'unworthy' members of the venerable council were purged and overall numbers reduced. Laws regulating marriage and social 'mores' for the highest echelons of society were passed; ${ }^{23}$ restrictions on the 'overseas' travels of senators, without imperial consent, introduced. ${ }^{24}$ Later came rules for the geographical composition of the portfolios of landed estates which constituted the backbone of senatorial wealth. ${ }^{25}$

As so often in court societies, loss of political autonomy was twinned with enhanced symbolism and a more elevated definition of aristocratic rank. Nothing perhaps illustrates this better than the fate of the consulship under the emperors. ${ }^{26}$ During the republic, the two annually elected consuls had been the leaders of the state. In the beginning of his reign Augustus had, therefore, almost as a matter of course reserved

${ }^{21}$ The reconstituted republic under the emperors is an exemplary instance of an "invented tradition", in the sense of Eric Hobsbawm and Terence Ranger, eds., The Invention of Tradition (Cambridge 1983). Paul Zanker, Augustus und die Macht der Bilder (Munich 1987), for the novel ideology and symbolism projected by the imperial court under the guise of traditionalism.

${ }^{22}$ Greg Rowe, Princes and Political Cultures. The New Tiberian Senatorial Decrees (Ann Arbor 2002), for a recent study of the enhanced symbolic presence in imperial society of dignity and hierarchy under the monarchy.

${ }^{23}$ Andrew Wallace-Hadrill, 'Family and inheritance in the Augustan marriage laws', Proceedings of the Cambridge Philological Society, 207 (1981) pp. 58-80; Catherine Edwards, The Politics of Immorality in Ancient Rome (Cambridge 1993), on moral legislation.

${ }^{24}$ Tac. Ann. 2, 59; Dio Cass. 52, 42, 6. Cf. Suet. Claudius 16.2. and Plin. Ep. X, 8-9 (the emperor Trajan granting Pliny leave of absence to tend to his estates during his tenure of the prefecture of the public treasury, aerarium Saturni).

${ }_{25}$ Plin. Ep. VI 19, 4 ; Hist. Aug. Marcus Aurelius 11, 8.

${ }^{26}$ Syme, Roman Revolution, pp. 372-74; Keith Hopkins and Graham Burton, 'Ambition and Withdrawal: the senatorial aristocracy under the emperors', chapter 3, in: Keith Hopkins, Death and Renewal (Cambridge 1983) pp. 120-200. 
one of these positions for himself. But that bred frustration and resentment among the senators who saw their prospects of achieving the highest republican magistracy significantly reduced. After a few years, and prompted by the detection of a conspiracy, Augustus decided that he could do without the office. The consulship now reduced mainly to a symbolic and ceremonial position, the practice developed of annually appointing more than the two customary incumbents. The pair appointed at the beginning of the year would resign after a few months and thus make room for a variable number of substitutes, so-called suffect consuls, to take up the magistracy in turn. Opportunities for aristocratic advancement significantly expanded through the agency of the emperor.

Successful participation in aristocratic political life now depended on the favour and patronage of the monarch. The Roman aristocracy had not primarily been defined by hereditary titles and rights, but through office-holding, renewable in each generation, in the service of the republic. With the monarchy, senatorial rank was made hereditary, though through three generations only, but all the traditionally important markers of high aristocratic status, full membership of the senate and access to high political office, were to a very large extent left at the emperor's discretion to grant or deny. ${ }^{27}$ Not only the consulship, but all of the old hierarchy of republican offices was transformed into a more firmly settled career in the service of the ruler. ${ }^{28}$ The appointment of provincial governors was wholly controlled by the emperor. Those who went to provinces with military garrisons were simply designated as legati Augusti, 'deputies' of the emperor. Where once political competition had focused on the popular assemblies, it now revolved around the emperor's household. Aristocrats vying for the trappings of power, wealth and prestige were, again to speak in Elias' terms, pitted against each other in a monopolistic game with the

27 On the emperor as a patron of the aristocracy, see Millar, Emperor in the Roman World, chap. 6; Richard P. Saller, Personal Patronage under the early Empire (Cambridge 1982), chap. 2 and Jon E. Lendon, Empire of Honour (Oxford 1997). Anton von Premerstein, Vom Werden und Wesen des Prinzipats (Munich 1937) was pathbreaking. An element of elections remained in the selection of the senate, but monarchical influence operated on many levels from direct appointments, to permission to seek election as well as denying unwanted candidates access.

${ }_{28}$ Werner Eck, 'Part II: Government and Civil Administration', Chaps. 4-7, in: The Cambridge Ancient History, Alan Bowman, Peter Garnsey and Dominic Rathbone, 2nd ed., vol. XI (2000) pp. 195-292 surveys the details. 
emperor as the final arbiter of rank and privilege..$^{29}$ In short, the old republican order had been absorbed within the social configuration of a court society.

The term society is important here. Roman nobles continued to have their own establishments in the capital. Augustus chose to live in conspicuous modesty and could not aspire to accommodate most of the elite within his dwellings on a scale comparable to that attempted by Louis XIV with Versailles. This would gradually change, however, as the imperial palace swelled effectively to take over all of the Palatine Hill. But long before that, aristocratic life had been reorganised in courtly fashion with Rome as its scene, defined increasingly by the proliferating monumental architecture of the Caesars. ${ }^{30}$ Here was enough of state religious ceremony, pageantry and public shows to keep the entire senatorial cohort both busy and bored. In the morning, it became established practice that senators would show up regularly at the imperial audience. A senator would be considered a 'friend' of the emperor, 'unless specifically renounced'-the latter amounting to a political death sentence and frequently a real one as well. ${ }^{31}$ Already under Augustus the senate began on many occasions to meet in what was to all intents and purposes a 'wing' of the imperial palace, namely in the library of the temple of Apollo which the emperor had built in connection to his domus. ${ }^{32}$ Soon scions of noble families would be brought up in the palace together with the imperial off-spring; and through a complex web of matrimonial alliances, the ruling house of the Julio-Claudians ended up absorbing almost the entire old nobility. ${ }^{33}$

As befits a court, sycophancy and conceit, flattery and pretence belonged to the order of the day. Self-restraint and polishing of social

${ }^{29}$ Cf. Hopkins and Burton, 'Ambition and Withdrawal', pp. 149-176; Flaig, Den Kaiser herausfordern, chap. 2.

${ }^{30}$ Paul Veyne, Le pain e le cirque. Sociologie historique d'un pluralisme politique (Paris 1976) pp. 638-641. The long period for court and aristocracy to become integrated suggested by Winterling, Aula Caesaris, seems unnecessarily protracted and puts too much emphasis on formal senatorial residence in the palace. Zanker, Augustus und die Macht der Bilder, pp. 59-61 on the relative modesty of Augustus' private domus, compensated in part by the construction of the adjoining temple of Apollo.

${ }^{31}$ Paterson, 'Friends in high places', p. 143.

32 E.g. David L. Thompson, 'The Meetings of the Roman Senate on the Palatine', American Journal of Archaeology, 85 (1981) pp. 335-339.

${ }_{33}$ Pani, La Corte dei Cesari, p. 11. 
mores to master the rigid decorum required to play the game of politics in the ambience of the ruler became de rigueur, as described in Wallace-Hadrill's contribution to this volume. With the formation of a court, the traditional aristocracy also found itself facing the increasing influence of the emperor's domestics, slaves and freedmen, as well as family. These groups benefited from their proximity to the ruler to carve out for themselves positions of power and influence. Aristocratic opinion would harp on tirelessly about the disgrace and humiliation involved in having to deal with such lowly people, perhaps even having to beg for favours. ${ }^{34}$ But in the absence of an elaborate bureaucracy, much of the administration had to be staffed from within the emperor's own and increasingly vast household. In Rome and across the Empire, significant numbers of imperial freedmen and slaves were employed in governmental jobs. ${ }^{35}$ Apart from these, a parallel hierarchy of offices gradually developed to be manned from among the members of the second aristocratic order, the equestrian. ${ }^{36}$ Previously the knights used to be thought of in terms of a rival commercial class, but this alternative branch of the élite was in fact drawn from the same layer of wealthy landowning families as the senate. ${ }^{37}$ Among the positions reserved for equestrian service were particularly important posts which emperors could not as safely trust to senators, their peers, for fear they might use them to make a rival bid for power. These jobs included positions such as governor of the vitally important province of Egypt, prefect of the Roman grain supply and of the praetorian guard, the legionary cohorts stationed in Rome as the emperor's élite corps.

To sum up, the Roman emperors presided over a political order which had undergone significant reform and modification to suit the

\footnotetext{
${ }^{34}$ Examples are legion, a good illustration is Seneca's spiteful Apocolocyntosis, a satire on the apotheosis of Claudius which imagines the defunct emperor being rejected by the Olympian gods and relegated to the underworld. Here justice is finally done when Claudius is reduced to slavery and made to serve as a secretary to a freedman of Aeacus, judge of the underworld. This was a suitably humiliating and disgraceful punishment for an emperor that had allowed himself to be dominated by his own slaves and freedmen who in consequence had been able to tyrannise and humiliate the senators.

${ }_{35}$ P.R.C. Weaver, Familia Caesaris: A social study of the emperor's freedmen and slaves (Cambridge 1972); G. Boulvert, Esclaves et affranchis impériaux sous le HautEmpire romain: Rôle politique et administrative (Naples 1970). 1950).

${ }^{6}$ H.G. Pflaum, Les procurateurs équestres sous le Haut-Empire romain (Paris

${ }^{37}$ Cf. Saller, Personal Patronage, pp. 77-78, p. 139 on the close social integration of senators and equestrians.
} 
needs of monarchy. During the first and second centuries CE, the emperors would slowly, but inexorably effect a profound change in the composition of the aristocratic elite. The senate of the late second century CE was a very different body from the senate which had existed in the times of Augustus. ${ }^{38}$ Most significantly many members of dominant provincial families had been recruited into its ranks, not always without resentment it is true. Claudius' proposal to admit leading nobles from Gaul to the ranks of the senate was not received with unequivocal approval by the body. Titus on ascending the throne felt compelled to put an end to his relationship with Queen Berenike, a member of one of Rome's royal client dynasties in the East, as a token of his dedication to the interests of the Roman aristocracy. But this kind of resistance never hardened into an unbridgeable fault line. Ethnic identity was not strong enough to preserve the integrity of the senate in the long run. ${ }^{39}$ Rank and hierarchy were too important in fashioning senatorial status to seal off the political body. In each generation some aristocratic families would fail to reproduce themselves; others would simply withdraw from political life. Court politics was a dangerous business. The hazards were aggravated by the ruinous costs of participating in the conspicuous consumption of upper-class life in the imperial capital. Most families would not be able to maintain more than a few heirs at the level of existence required of aristocratic life in the proximity of the emperor. Restricting the number of children, however, increased the risk that none would survive to adulthood. The senatorial aristocracy was in constant need of replenishment. ${ }^{40}$ The desire of senators to form advantageous marriage alliances and build up strong networks of powerful allies made resourceful provincial aristocrats attractive partners. Over the long-term, senators therefore ended up collaborating with the emperors in gradually admitting some provincial families into their midst. ${ }^{41}$

\footnotetext{
${ }^{38}$ Sergio Roda, 'Il Senato nell'alto impero Romano', in: Il Senato nella Storia (Rome 1998) for a recent survey of the development of the Roman senate under the emperors.

${ }^{39}$ CIL XIII 1668 (speech of Claudius); Tacitus, Ann. 11, 23-24 (for an account of the debate, partly hostile, which arose in response to Claudius' proposition); Suet. Titus 7, 2. Benjamin H. Isaac, The Invention of Racism in Classical Antiquity (Princeton 2003) on ethnic prejudice.

${ }^{40}$ Hopkins and Burton, 'Ambition and Withdrawal'.

${ }^{41}$ Saller, Personal Patronage, pp. 73-77 and chaps. 4-5 on the role of senators as brokers; Ramsay MacMullen, Corruption and the Decline of Rome (New Haven 1988)
} 
The failure of the Roman senate to turn itself into a closed hereditary aristocracy and its dependence on imperial patronage is, incidentally, a characteristic which has often been connected with the prebendal, 'slaves on horses', service élites of Muslim monarchies and empires. To return briefly to our Persianate comparison, membership of the Mughal nobility never became restricted to the group of 'original' conquerors. Mughal rulers continued to admit substantial numbers of defeated provincial nobles as well as Persian and other immigrants into the ranks of the corps of imperial mansabdars. ${ }^{42}$ The court enabled the rulers of both the Roman and Mughal empires to reach out from their core 'constituency' to attract men of power and ambition from wider contexts. Attainment of the highest rank and position thus remained to a significant degree dependent on imperial service and the governing élite was turned into a cosmopolitan aristocracy. The emperor's court became a vehicle of provincial integration. Thus, through the workings of imperial patronage, the composition of the Roman senatorial aristocracy was drastically changed from a group exclusively of Italian families to one with a majority of members originating in the provinces by the late $2 \mathrm{nd}$ century $\mathrm{CE} \cdot{ }^{43}$ The institutions of the republic had been grafted onto the imperial court.

The close intermingling of republican institutions with the imperial household can be seen very clearly from the manual describing the administration of the Roman water-supply written by the senator and prominent noble Frontinus, public water commissioner in the reign of Nerva. ${ }^{44}$ The aqueducts of Rome were maintained by two gangs of slaves. One had been donated by Agrippa, the designated number 2 of Augustus, to the republican state treasury, the aerarium. The other, the larger one, belonged to the imperial privy purse, the fiscus. Both, however, served under the same magistrate, a public commissioner appointed by the emperor. As is clear, the boundaries between household and republic were permeable and porous. This impression is only

pp. 75-76 with fig. 15 analyses a network based in the Lycian aristocracy and the complex web of alliances which saw it penetrate the senatorial élite.

${ }^{42}$ M. Athar Ali, The Mughal Nobility under Aurangzeb (Oxford 1997), chap. 1 for the composition of the Mughal nobility. Patricia Crone, Slaves on Horses: The Evolution of the Islamic Polity (Cambridge 1980) for the "slaves on horses" tradition of Islamic state-craft.

${ }^{43}$ Mason Hammond, 'Composition of the Senate, AD 68-235', Journal of Roman Studies 47 (1957) pp. 74-81.

${ }^{44}$ Frontinus De Aquis II, 116-118, citations from 118. 
reinforced when we read that in the reign of Domitian (81-96), the income from the sale of water-rights used to pay for the 'state' gang had been transferred from the aerarium to the fiscus. Nerva (96-98), in turn, had reversed this decision by 'his sense of justice' and returned the right to these incomes to 'the people'.

\section{A Contested Arena}

At first sight, the last act may not seem to fit into the image of a court domesticating its aristocracy. It is difficult to see why an emperor in such circumstances would bother to make such a gesture to 'the people. ${ }^{35}$ Observation of ceremony and symbolic acts, however, were an important part of the semantics of the political discourse. ${ }^{46}$ The intricate manipulation of formality and symbolism may be illustrated from the official decision of the senate in the cause celebre involving the prominent noble Cn. Piso. ${ }^{47}$ During his governorship of Syria he had fallen foul of Germanicus, the adopted son of the emperor Tiberius, who had been granted superior powers and sent on a special mission to sort out the Roman Middle East. Piso, a proud nobleman and old 'friend' of Augustus, was accused of insubordination and suffered the intolerable affront of being thrown out of his province by

\footnotetext{
${ }^{45}$ Additional confirmation that this should not be interpreted as lack of domestication may be sought from the fact, that Frontinus proudly declares that he could do without his public lictors when he ventured into the countryside around Rome. He was secure by the authority of imperial appointment (auctoritas a principe data pro lictoribus erit), De Aquis II, 101.

${ }^{46}$ It is in this perspective that the maintenance of republican forms takes on significance. The need to take seriously the republican formalities of the Principate was addressed by Eder, 'Augustus and the Power of Tradition. The Augustan Principate as binding link between Republic and Empire', in: Between Republic and Empire. Interpretations of Augustus and His Principate, Kurt Raaflaub and Mark Toher, eds. (Berkeley; Oxford 1990) pp. 71-122. But his view that the republic continued unabated fails to take proper account of the dramatically changed relations of power.

${ }^{47}$ The senatorial decree containing the judgement in the case of Piso is preserved on an official inscription, recently recovered in Spain. The text of the S(enatus) C(onsultum) de Cn. Pisone Patre was published by Eck, Caballos and Fernandez [Werner Eck; Antonio Caballos and Fernando Fernandez, Das senatus consultum de Cn. Pisone patre, Vestigia 48 (Munich 1996)]. The official version is complemented by the copious narrative of Tacitus in the 2nd and 3rd book of the Annals which provides an impression of the competing claims and rival factions involved in the whole affair, cf. Miriam Griffin, 'The Senate's Story', Journal of Roman Studies 87 (1997) pp. 249-263.
} 
Germanicus. ${ }^{48}$ Following this, Germanicus had died (CE 19). He and his powerful adherents believed that he had been poisoned by Piso who did nothing to improve his delicate situation by returning to his former province and attempting to win back his command by military force. This was in any case an act of open rebellion and could not easily be condoned. When Tiberius, whose tense relationship to the deceased was well known, came under suspicion for being the mastermind behind the whole affair, the fate of Piso was sealed. Tiberius courteously handed over the conduct of the criminal trial to the senate. Here the influential faction of Germanicus, thirsting for revenge, could find retribution while Tiberius displayed his liberal disposition and respect for the senatorial aristocracy. Piso would enjoy the privilege of being judged by his peers rather than behind the 'closed' doors of the palace. At the same time, an example would be made of Piso's 'feritas/wildness' to remind other leading nobles not to forget themselves and overstep the bounds of loyalty in the service of the emperor and his house. ${ }^{49}$

Piso committed suicide before the trial was concluded. Posthumously the senate reached a verdict of treason: the majesty of the imperial house had been slighted. ${ }^{50}$ The properties of Piso were confiscated and awarded to the old republican treasury, the aerarium, bar some pastures in the province of Illyricum. A gift from Augustus, these were now to be returned to Tiberius and the fiscus. The emperor, in other words, took care not to appear capricious and grasping after aristocratic property. This message was further underlined by the provisions made for the noble offspring of the condemned traitor. From

${ }^{48}$ The official version glosses over Germanicus' role in the departure of Piso which is presented as his own reckless act (SC de Cn. Pisone Patre, 1l. 48). Any person, however, who would contemplate returning to his abandoned province to try and win back the command with recourse to military action, is not likely to have left his province voluntarily. Whatever the formalities, Tacitus's judgement must in essence be correct.

${ }^{49}$ SC de Cn. Pisone Patre, 1l. 27. The official application of the word feritas, denoting an untamed and wild state, to describe the transgression of Piso is not insignificant in a discussion of Elias. The notion of domestication did enter into relations between emperor and nobles. But as is clear from the senator Seneca's treatise On Anger, book 3 , the idea had implications for both parties. The emperor, no less than the successful courtier, should know how to discipline and control his anger. William V. Harris, Restraining Rage: The Ideology of Anger Control in Classical Antiquity (Cambridge, Mass. 2003) chaps. 9-10, surveys debates about anger in Roman politics.

${ }^{50}$ SC de Cn. Pisone Patre, 1l. 32-33: "neglecta Maiestate domus Augustae". 
the aerarium, it was immediately decreed to return to his two sons their half portions of the confiscated family estate; and the daughter was awarded a separate fund. The head had fallen, but the noble house was allowed to continue..$^{51}$

While there can be little doubt that the official judgement of the senate bore the stamp of the emperor's version of the conflict, it is also clear that this incident cannot easily be reduced to a simple case of the monarch disciplining a defiant and querulous nobleman. Behind the obstinate resistance of Piso to Germanicus, a significant part of the aristocracy suspected the manipulating hands of Tiberius stirring up trouble for his adopted heir. The condemnation, in their version, was forced on the emperor as a face-saving act and a victory for the opposition to his reign. It was and is impossible to decide about the 'truth' of the opposing versions; it is also beside the point. Once the events up to and after Germanicus' death became part of the struggle for power, the competing versions, aided by a thick mist of rumours and allegations, took on political existence. Whether they were literally true was immaterial; what mattered was whether they could be made to appear true. In such questions, the emperor was not the sole arbiter. He was confronted by competing claims and would often have to make concessions to opposing camps. Indeed, in this case Tiberius was far from in control of the situation. The extraordinary extent to which attempts were made to publish the official version on inscriptions around the empire is a strong indicator. ${ }^{52}$ The position of Tiberius was a precarious one. At the death of Augustus some legions had in fact attempted to proclaim Germanicus as new emperor. The mother and the wife of Germanicus were the sister and grandchild, respectively, of Augustus. This arguably made him more truly 'royal' than Tiberius who was himself adopted by Augustus and only chosen as his successor as other preferred options had died prematurely. Even though Germanicus had stayed loyal, the adopted son of the reigning emperor remained a potential rival and a focus for the aspirations of the enemies of Tiberius. High hopes were pinned on the junior Caesar.

SC de Cn. Pisone Patre, 11. 84-105.

52 A point well made by Griffin, 'The Senate's Story', p. 260. Cf. the observation of Paterson, 'Friends in high places', p. 132 on the competing interpretations of Marc Antony's attempt to offer Julius Caesar the royal diadem. 
To make things even more complicated and increasingly tense, Tiberius also had a 'real', slightly younger son of his own, Drusus. The unexpected death of Germanicus had paved the way for Tiberius' blood-line to the imperial purple. Many looked in the direction of those who stood to benefit to identify the person responsible for the tragedy. 'The whole state was up on its toes...', as Tacitus saw with unfailing judgement, 'would Tiberius be able to contain and repress his sentiments. At no other time was the people more intent on allowing itself the freedom of whispered critique and suspicious silence against the princeps. ${ }^{53}$ In those circumstances, had Tiberius decided to let Piso go, it would have been seen as a sign of his complicity in Germanicus' death, or at least in the conflict between the latter and Piso, and thus further alienate a powerful segment of the imperial family and aristocracy. On the other hand, by allowing the condemnation of Piso he laid himself open to the complaint that he would sacrifice high-ranking nobles to serve his own purposes and security. Either way, the court did not function as a battleground where the rules were defined by the emperor alone. ${ }^{54}$

\section{A Vehicle of Negotiation and Compromise}

To be a successful instrument of rule, the imperial court could not merely be applied to discipline or destroy the aristocracy. Such a course was decried as murderous tyranny and lacked legitimacy. ${ }^{55} \mathrm{~A}$ patrimonial emperor did not dispose of a vast, fully-fledged independent bureaucracy to govern his far-flung territories. As Dio Cassius

${ }_{53}$ Tac. Annales III, 11 (my translation).

${ }^{54}$ The analysis of Rowe, Princes and Political Cultures, focuses too much on the official image projected of social and ideological consensus. Even within the elite we have to recognise that such notions were contested and variously interpreted by different groups to serve their own purposes.

${ }_{55} \mathrm{Cf}$. The tragedy Octavia, which makes a poignant portrayal of the terrors of Nero's court, provides a good impression of the ideology of critique directed against the "unrestrained monarch". He is presented as a bloodthirsty tyrant who relies on fear and the sword (vv. 492-532) and is contrasted with the good king who preserves the peace and enables men to prosper (vv. 472-91). Matthew B. Roller, Constructing Autocracy. Aristocrats and Emperors in Julio-Claudian Rome (Princeton 2001), chap. 4 for a recent discussion of the opposition between tyranny and good lordship in Roman political discourse. However, he is mistaken to see these as representing two competing models of monarchy; rather they regulate a structural conflict characteristic of the court in general. 
observed, the emperor needed 'the best men', that is the aristocracy, to lend lustre to his reign and assist him in running the empire. ${ }^{56}$ Emperors who failed to maintain a tolerable dialogue with the senatorial aristocracy were steering a dangerous course. Direct, intense and sustained confrontation locked emperor and political élite in a lethal embrace. Alienated by the detection of a conspiracy against his life, the young Caligula withdrew in disgust from the senate and embarked on a campaign of public humiliations and vindictive purges. This has earned him the reputation of a madman. But that was hostile aristocratic slander; it is hard to credit that someone truly mad should have been able to hold the reigns of the empire and mount a serious challenge to powerful circles in the aristocracy. Nevertheless, by intensifying conflict and refusing dialogue, Caligula literally chose a dead end. He left the political élite no way out; compromise was impossible. Several conspiracies followed in close succession till finally one succeeded in the fourth year of his reign. ${ }^{57}$

The Roman court, therefore, was not simply a 'revolutionary' institution; it also needed to make overt concessions and appeals to established tradition in order to attract and appease an aristocracy which jealously guarded its privileges and standing. This is not uniquely a characteristic of the Roman court. In the quotation I used at the beginning, we saw the Mughal emperor stand down from his demand to receive prostration in the form of the sijdah in order to placate his critics who denounced the act as ungodly and against religious tradition. Islam could, as in the writings of Badauni, serve as a basis for articulating critique of Mughal rulers and hold them to the ways of proper scripture. ${ }^{58}$ By pledging to be the champion of the mos maiorum, that

${ }^{56}$ Dio Cassius 52, 9 \& 19; cf. Norbert Elias, Über den Prozess der Zivilisation, bd. 1-2, Edition Suhrkamp (Baden-Baden 1997) vol. 2, pp. 156, 280-284 and 378-79. As Duindam, Vienna and Versailles, pp. 18 and 279-87 points out, aristocrats were not simply domesticated; many were able to claim rich and extensive rewards in return for their loyalty and service.

57 Aloys Winterling, Caligula. Eine Biographie (Munich 2003), chaps. 3-5 describe well the gradual intensification of conflict between Caius and the aristocracy.

${ }^{58}$ Badauni's critique of Akbar, Mughal emperor 1556-1605, is contained in the Muntakhab al-Tawarikh (an English translation in 3 volumes is available as Muntakhab al-tawarikh [a general history of India from the Mohammedan conquest to A.H. 1004 (CE 1595/6)] / ed. by W.N. Lees et al., Calcutta 1884-1925); For analysis, see e.g. Ali Anooshahr, 'Mughal historians and the memory of the conquest of India', Indian Social and Economic History Review 43 (2006) pp. 275-300 emphasising the anti-absolutist nature of Badauni's critique of Akbar, Mughal emperor (15561605), and Rosalind O'Hanlon, 'Kingdom, Household and Body History, Gender and 
is the old republican traditions, Roman emperors attempted to accommodate aristocratic interests. When Nero, for instance, in a speech made early in his reign promised to 'keep his household and the republic separate', he was not thinking of establishing a civil service in our sense of the term, with equal and impersonal treatment of all. Nor did he intend to withdraw the vast resources at the disposal of the imperial patrimony from the running of the state. Any such scheme would have jeopardised the operation of government. Quite the reverse, it was a pledge to give preferential treatment to the republican aristocracy, rely on his peers and admit them to a share in the business of government rather than allow his slaves, freedmen and female relations to influence decisions, such as his predecessor Claudius had been accused of doing. Senate and Princeps were to be partners in power: that was the message. ${ }^{59}$

Aristocratic opinion presented the emperor with an ideal of personal rule. Emperors were praised for taking a personal hand in the execution of government. Edifying tales of hard-working monarchs who would give attention to every detail and deprive themselves of sleep in order to master the many tasks of rule were part of the moral discourse of kingship in extensive empires as well as in smaller monarchies. Ammianus Marcellinus noted with admiration how the emperor Julian surpassed even Alexander in managing to keep to a rigorous regime with nights divided between rest, public business and intellectual pursuits. The latter needed the assistance of a silver ball to help him stay alert, the reader is told. Held over a bronze basin by an outstretched arm, the ball would drop as the body of the Macedonian king was overtaken by sleep. The noise caused by the fall would then wake

Imperial Service under Akbar', Modern Asian Studies 41, 5 (2007) pp. 1-35 relating Badauni's critique to resistance against Akbar's attempts to "domesticate" his nobles by regulating their masculinity and sexual mores.

${ }_{59}$ Tac. Ann. 13, 4, 2. Winterling's comment (Zwischen "Haus" und "Staat", p. 107) that the discourse opposing imperial domus to res publica presented the court "als unzulässige Vermischung der Sphären von domus und res publica" is inadequate. Rather the dichotomy structured a debate over the character of the imperial monarchy. Was government to be based on a closed household or on a domus turned into a real court open to aristocratic influence. Tacitus, therefore, goes on to relate a tense moment at Nero's court. The emperor is in the process of receiving a deputation from Armenia as his mother decides to join him on his tribunal and preside next to him. The court looks on in consternation. But Seneca, senator and leading advisor of Nero, averts the scandal by ordering Nero to descend from the platform and as a dutiful son meet his mother before she ascends $(A n n .13,5)$. 
him up again. Julian, however, needed no such devices and would wake up at will. ${ }^{60}$ The notion of the ever-attentive monarch similarly reverberates in Mughal ideas of kingship. Court ritual carefully aimed to make the Timurid rulers appear visibly performing the duties of government. In his memoires, the emperor Jahangir even congratulates himself on having built up an ability to go with very little sleep. For 'this has two benefits. One is awareness of what is going on in the realm, and the other is wakefulness of the heart to remembrance of God. ${ }^{61}$ But in practice no ruler, however diligent, could hope to stay on top of the flood of requests and petitions for favours reaching his court: the more extensive the territories and powerful the lord, the greater the challenge. A court had to work through exclusion.

The imperial aristocracies were under no illusions in that respect. The all-important issue, therefore, was to whom the ruler was willing to lend his ear. From their perspective, the monarch had to make himself accessible, especially to them: the emperor should seek his courtiers among 'the best men' it was constantly repeated. ${ }^{62}$ That would enable the aristocracy to defend and promote its interests at court. Roman emperors can be seen responding to such demands, for instance, by declaring their palace a public house rather than a private residence. ${ }^{63}$ Another such gesture was the increasing use of equestrians, the second aristocratic order in Roman imperial society, to man some of the most important secretarial positions in the imperial household (in charge of Latin and Greek correspondence, of accounts and of legal hearings) instead of the controversial imperial freedmen. The court evolved not merely as a disciplining mechanism to pacify the nobility; this was only one dimension of a more complex situation. Monarch and aristocracy were interdependent: this was the basis of the court as a social institution. Absolute in name, the emperors were by no means free to do as they pleased, but also had to make service to them appear attractive. This gave the aristocracy a measure of bargaining power and made the court not simply a tool in the hands of the ruler. It functioned even more as an institution of government, allowing forces

\footnotetext{
${ }^{60}$ Amm. Marc. XVI, 5, 4-5.

${ }^{61}$ The Jahangirnama, Wheeler M. Thackston, trans. (New York; Oxford 1999) p. 265; Ain-i-Akbari, Book I, chaps. 72-73 (trans. Blochmann, pp. 153-157). Koch, 'Diwan-i 'Amm and Chihil Sutun', pp. 143-165 on Mughal audiences and accessibility.

${ }^{62}$ A stock theme of imperial political discourse, cf. also Aristeides, Oration To Rome, chaps. 59 and 64.

${ }^{63}$ Plin. Pan. 47, 4.
} 
to be balanced against one another and the relative strength of participants to be determined, in other words, a theatre of contact and integration where ruler and aristocracy met to negotiate the distribution of privilege, favour and power. ${ }^{64}$

Imperial government, therefore, was a fairly exclusive affair. The core of the Roman aristocracy under the principate comprised the body of 600 senators and a comparable, but probably smaller, number of equestrians in the emperor's service. Many more sought out the seat of the emperor, but access to his favour had more or less to be obtained through the mediation of either this select aristocratic group or the personal servants of the monarch. Between emperor and his realm was a screen of influential nobles and courtiers on whom he depended as much as they did on him. For the vast majority of the landed elites in the provinces which effectively ran government on the ground, the imperial court was a very distant centre. The dialogue here was much less intense and communication intermittent. As long as these groups remained within broad bounds of loyalty, they would frequently be able to fashion an image of the emperor which would serve their own purposes and prop up their position within local society. ${ }^{65}$ Much of

${ }^{64}$ Cf. Duindam, Vienna and Versailles, p. 319 who prefers to use the concept of integration rather than domestication to describe the interaction of monarch and aristocracy at early modern courts. Particularly in the analysis of Die höfische Gesellschaft, Elias placed the emphasis on the court as an instrument in the hands of the ruler (chap. 6). Nevertheless, he also made clear that the court could not be reduced to just this. The king was in a sense no less a prisoner of court ceremony and ritual than the nobles (pp. 206-221). Attempts to cancel privileges were fiercely resisted (pp. 133-135); and the ruler was under constant pressure from vast numbers to grant new favours (p. 209). This aspect of court life was brought further to the foreground in Über den Prozess, e.g. vol. 2, p. 285, where the French absolutist court is seen as a product of the historical process which led to greater concentration of taxation capacity and military power in the hands of the monarch through the growing interdependence of social and political elites; the king's power was shaped by the social figuration it was part of. In other words, domestication and integration perhaps need not be treated as mutually exclusive options, but rather as complementary aspects of a complex reality. The Roman court combined both functions; peaceful cooperation appears next to covert resistance and coercive subjection-the latter already described by Syme (Roman Revolution, p. 404) in the language of domestication, "the principes viri were tamed, trained and harnessed", independently of Elias.

${ }^{65}$ Cf. Duindam in his contribution to this volume about the court as a way of achieving a fairly loose integration of provincial aristocracies. Peter Garnsey and Richard Saller, The Roman Empire. Economy, Society and Culture (London 1987), chap. 2 (on Roman government without bureaucracy). M.N. Pearson, 'Shivaji and the Decline of the Mughal Empire', The Journal of Asian Studies 35 (1976) pp. 221-235 provides a comparable perspective on Mughal government. As pointed out by Keith Hopkins, 'Rules of Evidence', Journal of Roman Studies 68 (1978) pp. 178-186 in his review of 
the time, in other words, the challenge facing central authority was less one of domesticating the various levels of aristocratic society than one of avoiding being fully appropriated by such élite groups striving to promote their own agendas.

\section{Between Domestication and Tradition}

Occupied, almost to the point of obsession, with forms of greeting and paying obeisance to the monarch, Western commentators have been inclined to focus on the domesticating and disciplining aspects of Oriental imperial courts. Graeco-Roman political discourse defined itself in express opposition to the Persian style of monarchy. Greek and, later, Roman freedom was pitted against a vilified Oriental tyranny. Courts have, therefore, traditionally been presented as foreign elements in this world dominated by the city-state. The claim made by the Roman princeps to be the protector of the res publica has been understood as setting the Roman monarchy apart from the personal style of rule characteristic of patrimonial emperors. While it is undeniable that Roman republican traditions did lend the government of the Caesars some of its particular colouring, it has been the contention of this paper that it is precisely and paradoxically the survival of republican forms and traditions under the rule of the emperors which makes the Roman court comparable to other patrimonial regimes. Established traditions of political authority and privilege have generally been able to stamp their mark on the specific appearance of royal courts. No monarch, not even of the August and elevated kind with universal and imperial aspirations, could simply replace pre-existing political structures with an entirely new set-up of their own design. In order to rule successfully, a Mughal emperor, no less than a Roman, had, like other monarchs, to bow to traditional forms of authority such as Islam and Hindu kingship. Much of the time, domestication had to give way to compromise and negotiation.

Millar, Emperor in the Roman World, government through the court significantly limited the capacity of Roman emperors to penetrate provincial society. Clifford Ando, Imperial Ideology and Provincial Loyalty in the Roman Empire (Berkeley 2000) and Fergus Millar, A Greek Roman Empire. Power and Belief under Theodosius II, 408-450 (Berkeley 2006) tend to underestimate how few persons the dialogue between central authority and provincial elite involved, even at its most intense. 
The obvious inspiration for Elias' concept of domestication and its effects on aristocratic personalities is, of course, modern psychology. But behind the Freudian facade lurk ancient notions of the monstrous tyrant, often in Oriental dress, against which rulers were habitually warned in the sundry versions of Mirrors for Princes literature; rulers should know better than to reduce their nobilities to a condition of dependent slavery. Elias' main concern was to explain the process of modernization; in the realm of politics that meant the rise of the modern state characterised, in Weberian fashion, by the possession of a monopoly on the legitimate use of violence. Thomas Hobbes was among the first to consolidate this idea when he insisted that the state should be likened to the biblical monster of the Leviathan, striking fear into the hearts of the subjects to keep them in passive submission. ${ }^{66}$ In Elias' interpretation, the court became a key vehicle in the emergence of the modern coercive, or tyrannical, state. But the connection between the process of modernisation and the formation of court societies is complex, if not tenuous. Royal courts, after all, much predate the processes of modernization. Domestication and dependence have to be thought of in several different shapes and sizes and degrees of intensity, not all of them inter-linked with the development of modern state power. ${ }^{67}$ Adam Ferguson, a predecessor of Elias in charting the emergence of a modern, pacified civil society, noted with some wonder that:

The manners of the imperial court, and the conduct of succeeding Emperors, will scarcely gain credit with those who estimate probabilities from the standard of modern times. But the Romans were capable of much greater extremes than we are acquainted with. ${ }^{68}$

Freed from the processes of modernization, the notion of a domestication of the aristocracy may be reduced to just one facet of court politics. The position of an emperor like the Roman was strong, but he

\footnotetext{
${ }^{66}$ In chapter 20 of Leviathan Hobbes thus extended the ancient notion of despotism, as based on fear, to characterise sovereignty in general.

${ }^{67}$ Cf. Elias, Über den Prozess der Zivilisation, vol. 2, pp. 366-371; pp. 151-168 on the monopoly on violence and the court.

${ }_{68}$ Adam Ferguson, The History of the Progress and Termination of the Roman Republic (Edinburgh; London 1799) vol. 5, p. 404, and he continued: "Although it would be absurd to imagine such a satire levelled at the corruptions of a modern court, whose principal weakness is vanity, and whose luxury consists in ostentation; we must not therefore reject every supposed application of it to the pollutions of a Roman barrack" (p. 406).
} 
was not the monopolist of the modern state. The very size of his realm prevented that. Even if the Roman court exercised a strong pull and constituted a powerful influence on provincial aristocracies, it was still a long way off for most of the members of the local landed elites that administered and in many respects represented the imperial 'peace' on the ground. Court society while permeable to such groups comprised a much narrower segment of the aristocracy. From that perspective, the imperial court seems rather like an institution for maintaining a minimal level of central government and control. Contact with the subject population was to a very large extent mediated through a very select and privileged aristocracy. If the emperor exercised a profound influence on the lives of individual nobles, he was nevertheless heavily dependent on the collective; in the court, he was far from the sole actor and the nobility, even if it depended to a large extent on imperial patronage, not a powerless body, as Duindam rightly comments in his contribution on Vienna and Versailles in this volume.

The lasting attraction of Elias' conceptualisation, therefore, is more in his understanding of the court as a social configuration where the movements of individual agents are shaped by a set of common rules as in a game. But that game would frequently have resembled chess. The king may be the most important piece, but left to his own devices a fairly weak one. ${ }^{69}$ To function as an instrument of government, the imperial court both had to work towards domesticating its aristocracy and at the same time appeal to tradition and open itself to aristocratic demands. The Roman court was a complex and dynamic institution where the balance was constantly being (re)struck between these two opposing principles. The result was far from given and is reflected in the varying vicissitudes of Roman dynastic history. As the aristocracy risked being decimated and humbled by the emperor, the emperor had to avoid being caught in stifling tradition and ritual which reigned in his field of action and risked rendering him superfluous.

This paper began with a vignette from the Persianate world of Mughal India. We end with an image from imperial Rome describing the funeral rites of Septimius Severus (193-211). These culminated in a sumptuous cremation ceremony on the Campus Martius during which the dead emperor's spirit was supposed to ascend to the heavens

${ }^{69}$ Cf. the observation of Duindam, Vienna and Versailles, pp. 213-214 on the king being caught in the competitive struggles of his courtiers. 
and join the gods. But preceding the staged apotheosis of the ruler, another public display had been performed over several days. Outside the palace, a wax effigy of his body was placed in a bed. Around it assembled the senators and high-ranking women as if they were concerned family-members attending the sickbed of a dying father. 'For seven days these ceremonies continue', Herodian reported to his Hellenic readership, 'Each day the doctors come and go up to the couch, and each day they pretend to examine the patient and make an announcement that his condition is deteriorating. Then, when it appears he is dead, the noblest members of the equestrian order and picked young men from the senatorial order lift the couch up and take it along the Sacred Way... ${ }^{70}$ From one perspective, these rites are, of course, testimony to the power of the court to domesticate the senatorial aristocracy and recast it in the role of loyal and dutiful subjects. Seen from another angle, it is a demonstration of the independent potential of court ritual and ceremony; it could literally go on without the emperor, a puppet might just do. ${ }^{71}$

${ }^{70}$ Herodian IV, 2 (trans. Whittaker).

${ }^{71}$ I am much obliged to Peter Garnsey and John Hall for the helpful suggestions and perceptive comments they made to an earlier draft of this paper; and to the audience at the conference in Istanbul for constructive and inspiring discussion. Ancient Latin and Greek texts are cited using the customary system of abbreviations in Oxford Latin Dictionary and Liddell \& Scott, Greek-English Lexicon. 